\title{
PKM Utilization of Podcasts as Communication Media for Da'wah Broadcasting during the Covid Outbreak
}

\author{
Mohammad Bahrul Ulum¹, Nanang Qosim², Abdur Rahmad³, \\ Abdul Qohhar ${ }^{4}$, Mohammad Badrus Soleh ${ }^{5}$, M. Saifillah ${ }^{6}$, \\ Muhammad Effendi ${ }^{7}$
}

Universitas Nurul Jadid, Probolinggo, Indonesia 1,2,3,4,5,6,7 \{masrurul@unuja.ac.id 1,2,3,4,5,6,7\}

\begin{tabular}{ll}
\multicolumn{1}{c}{ Submission: 19/12/2021 Received: 31/12/2021 Published: 31/12/2021 } \\
\hline $\begin{array}{l}\text { Keywords: } \\
\text { Keywords: }\end{array}$ & condract. The COVID-19 pandemic requires people to adapt to current \\
podcast; & or create a crowd of people. Society is faced with virtual conditions in \\
broadcasting & every situation activity, especially in religious activities. The places of \\
communication; & worship are commonly closed. Today the implementation of prayer in \\
da'wah; & the congregation is used to avoid the spread of covid 19. This article \\
Covid-19 & aims to report the results of community service related to the use of \\
& podcasts as a medium of communication broadcasting da'wah in \\
& mosques. This service activity also provides convenience for mosque \\
& administrators in the East Probolinggo area to deliver propaganda. \\
& This service is expected to help mosque administrators understand \\
& and use podcasts to communicate religious activities. And able to use \\
& social media and communication media to deliver spiritual \\
& information and da'wah.
\end{tabular}

Katakunci:

Podcast, komunikasi penyiaran, dakwah, Covid-19

\begin{abstract}
Abstrak. Pandemi COVID-19 menuntut masyarakat untuk beradaptasi dengan kondisi saat ini yang melarang aktivitas yang melibatkan banyak orang atau membuat kerumunan orang. Masyarakat dihadapkan pada kondisi virtual dalam setiap situasi kegiatan, terutama dalam kegiatan keagamaan. Tempat ibadah biasanya tutup. Hari ini pelaksanaan sholat berjamaah digunakan untuk menghindari penyebaran covid 19. Artikel ini bertujuan untuk melaporkan hasil pengabdian masyarakat terkait penggunaan podcast sebagai media komunikasi penyiaran dakwah di masjid. Kegiatan pengabdian ini juga memberikan kemudahan bagi pengurus masjid di wilayah Probolinggo Timur untuk menyampaikan dakwah. Layanan ini diharapkan dapat membantu pengurus masjid memahami dan menggunakan podcast untuk mengkomunikasikan kegiatan keagamaan. Serta mampu menggunakan media sosial dan media komunikasi untuk menyampaikan informasi spiritual dan dakwah.
\end{abstract}




\section{Introduction}

Since the beginning of the emergence of the coronavirus in Indonesia, the government has issued several policies in which the Indonesian people are required to keep their distance from one another others at least one and a half meters. The Indonesian people are forced to stay at home and do all activities from home and limit activities outside the home such as school, college, and work. The activities that are usually carried out at home outside the house now has to be done at home by online (online) or traditional which is called online. This policy also applies to religious activities(Bruns, Kraguljac, \& Bruns, 2020). Based on the Circular of the Minister of Religion No. 15 Years2020 regarding Guidelines for the Implementation of Religious Activities in houses of worship in Indonesiacreate, a productive and safe community of covid during the pandemic. A Circular signed on 29 May 2020 includes guidelines for implementing religious activities in houses of worship during the pandemic, usually held in a congregation or collectively. It regulates core religious activities and social religious activities at home worship, based on the actual situation of the covid-19 pandemic in the house of worship, not only based on the zone's status that applies in the area. Religious activity done in places of worship has changed to being done at home (Tobroni, 2020). With these rules, places of worship that were previously crowded look Ionely without activity. One of them is in the mosques, which are usually their congregational prayer activities five times a day and on Friday perform Friday prayers. Every Friday prayer, there is always a lecture or sermon delivered, and every afternoon recitation activities and activities are held routine preaching. This activity is rarely done, and we hear about it again.

Problems related to worship at home during the pandemic are also felt by other religions such as Catholicism, Christianity, Hinduism, Buddhism and Hinduism Confucianism. Their religious activities change virtually, which is followed by their followers. Therefore, the problems that exist when the pandemic hits like it or not, like it or not like the community, are required to adapt to the current situation. Apart from adapting to current conditions, society must also adapt to technology. Because in the current era, everything is replaced by technology. This is one way to reduce patients with covid-19 and avoid the crowds in the community so that transmission does not spread everywhere (Usman, Aswar, \& Irawan, 2020). Technology in the future COVID-19 pandemic has played a significant role in helping the community's 
online activities. In the field of education, students who usually do school or face-to-face lectures are now done online through the application at their respective cellphones or laptops, as well as office workers who typically do work by going to the office now doing the work from home online through their respective computers or cellphones. Some health aspects are done online, such as consultations by patients who usually go to the hospital, which can now be done virtually (Yatimah, Kustandi, Maulidina, Irnawan, \& Andinnari, 2020).

The existence of technology during this covid-19 pandemic makes all activities easier for people at home, receive information quickly, and develop community creativity to utilize technology better. Therefore technology is one way to revive places of worship and prosper the deserted mosques again due to restrictions on activities by the government because of the covid-19 pandemic. With technology, activities such as preaching, recitation, and sermons can be implemented again. In this case, technology can also facilitate the implementation of religious activities. Through community service, this time done provides solutions to problems in the community. The problem that happens in the community is that they cannot participate in religious activities such as preaching, recitation, and listening to the sermon in the mosque. This issue occurred in the mosque East Probolinggo area. It's been a long time since religious activities at this mosque have stopped due to the pandemic covid-19. The administrators who are members of the Masjid Tak'Lim assembly try to comply with regulations imposed by the government. But they also want a permanent society that can hear the studies conducted by the mosque and the usual routine activities they do such as da'wah, recitation, and sermons. Starting from the above, the key to the problems in the mosque in the East Probolinggo area is podcast technology. Podcast media is a solution so that religious activities can continue. The podcast is currently a medium that is booming among entertainment. Podcasts convey information or clarification of artists who stumbled into trouble.

Podcasts are digital files in the form of audio that the listener must listen to download first to listen to the audio. This podcast is audio-streaming, so it is very different from radio (Fadilah, Yudhapramesti, \& Aristi,2017). The public has widely used this podcast to listen to the news and share repeatable knowledge. This publicity can be a distinct advantage of podcasts compared 
to the radio (Mayangsari \& Tiara, 2019). Podcasts can be listened to while waiting for the train, eating breakfast, and moments others and inserted into the gadget for more practicality. The podcast media can provide a solution regarding religious activities resulting from the pandemic (Asmi, 2019).

Problems regarding the lack of technological knowledge by mosque administrators, in this case, it is necessary to conduct training in the form of hands-on practice on operating equipment from downloading podcasts to creating da'wah broadcasts and other religions through podcasts. However, before the trial takes place, the presentation is theoretically given first to balance obtaining knowledge of both theory and practice. For this reason, through the communication science study program, The Faculty of Islamic Sciences, Nurul Jadid University seeks to provide training by taking advantage of developing modern technology. The technology is the media podcast given to mosque administrators.

\section{Method}

The need for training to minimize the problems expressed by partners become our basis for using podcast media activities. So, community service activities are a solution offered to overcome the problem. Then, this community service also aims to seek a way out so that religious activities at the mosque can continue to run. In carrying out the processThe activities carried out at the mosque in the East Probolinggo area go through three stages: planning, implementation, and evaluation.

\section{Result and Discussion}

\section{Planning Stage}

At the planning stage, we first observe the problems faced by mosque administrators. Furthermore, we assess that mosque administrators have to lack technological knowledge. Besides, they are also not capable of taking advantage of modern technology. Therefore, the Covid-19 pandemic has made them experience limitations in carrying out religious activities. This pandemic results in the administrator not delivering the da'wah directly to the congregation. Based on the results observations and interviews conducted, we identified that mosque administrator require hands-on 
practice to operate the equipment related to podcast media. In addition, presentations related to theories with modern technology are also needed to understand the mosque's management. Thus, mosque administrators also recognize the various uses of technology that can be used they use.

We conducted a workshop at the mosque in the East Probolinggo area in this early stage. The activity was carried out for two days. On the first day, we did a workshop by understanding the Podcast function and its use. Furthermore, Workshop participants who are also mosque administrators understand the importance of communication media that can be used for mosque development. On the second day, we do training how to use Podcasts. In addition, we provide an explanation related to the steps taken before broadcasting using Podcasts. In addition, we also introduce equipment commonly used in broadcasting Podcasts. Participants showed how to use and publish the results of da'wah broadcasts to the public.

\section{Implementation Stage}

In the second stage, after participants know how to use podcasts and understand other communication media used in religious activities in mosques, we continue with the practice. At this stage, the service team divided 40 participants into eight groups so that the method ran effectively and evenly. So that all participants can direct practice. Because practice, in this case, is critical to see if the participants understand what the speaker is saying. Some participants from mosque partners in the East Probolinggo area have a lot of enthusiasm for welcoming the training. So that from 40 participants divided into 1 group containing 5 participant members. The team provides training consisting of two practices: podcast practice as a beginner housing minimal equipment and can be accessed and downloaded quickly. Second podcast practice training using broadcasting equipment. Manufacturing stages podcasts include making podcasts on the Spotify, Joox, and Anchor applications.

\section{Evaluation Stage}

The third stage is an evaluation. After giving the material and practicing, the next stage is an evaluation. At this stage, the team will monitor the net 
broadcasting of da'wah carried out by mosque administrators in the East Probolinggo area. Evaluation carried out every broadcast is carried out to review the independence of participants implement the results of the workshops and practices carried out. This evaluation is essential to see to what extent the administrators can independently process content and use tools and broadcast. In this case, the team evaluates from a technical point of view of equipment and operations and from the content presented each time they broadcast. Based on the evaluation results, participants can operate podcast equipment. They can also carry out activities independent podcast creation. Of the 40 participants who made podcasts, 30Some of them are easier to use podcasts through the Spotify application. Besides, we also evaluate communication techniques and broadcasting techniques. Communication is not found a significant obstacle. It's just that participants initially found it challenging to carry out the recording process on broadcasting techniques and provide tools for recording podcasts. However, this obstacle can be overcome through assistance provided by the team. We also provide feedback regarding podcasts that have been done and published well via Joox or Spotify. In the future, the mosque congregations do not feel bored listening to da'wah through mosque podcasts.

This activity shows that technology has a significant positive impact during the COVID-19 pandemic. It is in line with the results of Komalasari's research (2020), which shows that technology's superiority plays an essential role for everyone. Podcasts are modern technological media that can facilitate religious communication. In line with Indriastuti and Saksono (2014), podcasts can be used as learning resources. In the practice of using podcasts, it shows that participants can make podcasts as a source of learning broadcast communication. Media strategy Da'wah through this podcast shows its effectiveness because it can transform religious knowledge to society. During the implementation process, participants listen to the explanations of the presenters and participate in creating podcasts. They plan with the mosque management team and adjust the da'wah theme raised. Participants also carry out the download and upload process independently. So podcasts can become an alternative media for religious activities in mosques (Ummah, Khairul Khatoni, \&Khairurromadhan, 2020). Munthe's research (2018) shows that radio is used as a medium of da'wah communication. But since the advancement of technology and the covid 
pandemicDa'wah activities no longer only use radio. Podcasts are an easy alternative used both in da'wah and other religious activities. Besides that, this service activity also encourages to provide knowledge to participants in introducing modern technology and its use. Even in practice, there are still obstacles when making podcasts, although the service team can deal with them.

\section{Conclusion}

Cooperating with religious opinion leaders and community officials continuously digging information, technology and increasing creativity in technology improvement in the future the covid-19 pandemic, which requires people to adapt to technology, so that did not lag in its development. This case encourages continuing to the proper mosque despite limitations and restrictions during the pandemic. The mosque constantly remains active in religious activities and not vacuum even though there is an epidemic virus. The Covid pandemic has forced religious activities to be limited to avoid crowds that cause the spread of the virus. Religious activities such as lectures, sermons, da'wah, and recitations initially held routinely have become a vacuum due to activity restrictions. The results of this dedication show that activities can be carried out to reactivate religious activities through training and practice podcast media use. The mosque administrators' participants have difficulties delivering religious activities due to understanding information technology. So training how to use podcasts is the first step the team takes dedication to increase participants' knowledge regarding digital media in da'wah. In addition to da'wah, this training also provides participants with material on modern technology, which can be used for lectures and other religious activities. Besides training needs in technology, the administrators are also given the material on communication broadcasting and public speaking techniques or public speaking. In the future, this service will be carried out not merly on the mosque environment but also in other places of worship. So, even though plague or disaster come the administrator of the place of prayer, you don't have to surrender to the situation, but rather improve creativity by finding a way out by utilizing developing technology. 


\section{References}

Asmi, A. R. (2019). Pengembangan Media Pembelajaran Audio berbasis Podcast pada Materi Sejarah Lokal di Sumatera Selatan. Historia: Jurnal Pendidik Dan Peneliti Sejarah, 3(1), 49-56. https://doi.org/10.17509/historia.v3i1.21017

Bruns, D. P., Kraguljac, N. V., \& Bruns, T. R. (2020). COVID-19: Facts, Cultural Considerations, and Risk of Stigmatization. Journal of Transcultural Nursing: Official Journal of the Transcultural Nursing Society, 4, 1043659620917724. https://doi.org/10.1177/1043659620917724

Fadilah, E., Yudhapramesti, P., \& Aristi, N. (2017). Podcast sebagai Alternatif Distribusi Konten Audio. Jurnal Kajian Jurnalisme, 1(1), 90-104. https://doi.org/10.24198/kj.v1i1.10562

Komalasari, R. (2020). Manfaat Teknologi Informasi Dan Komunikasi Di Masa Pandemi Covid 19. Tematik, 7(1), 38-50. https://doi.org/10.38204/tematik.v7i1.369

Mayangsari, D., \& Tiara, D. R. (2019). Podcast Sebagai Media Pembelajaran Di Era Milenial. Jurnal Golden Age, 3(2), 126. https://doi.org/10.29408/goldenage.v3i02.1720

Munthe, M. (2018). Penggunaan radio sebagai media komunikasi dakwah. Jurnal Komunikasi Islam, 5(2), 1-18.

Saksono, W. T., \& Faiza, I. (2014). Podcast Sebagai Sumber Belajar Berbasis Audio Audio Podcasts As Audio-Based Learning Resources. Jurnal Teknodik., 18.(1), 304-314.

Tobroni, F. (2020). Pembatasan Kegiatan Keagamaan dalam Penanganan Covid-19. Jurnal Komunikasi Hukum Universitas Pendidikan Ganesha, 6(2), 369-395.

Ummah, A. H., Khairul Khatoni, M., \& Khairurromadhan, M. (2020). Podcast Sebagai Strategi Dakwah Di Era Digital: Analisis Peluang Dan Tantangan. Komunike, 212(2), 234. https://doi.org/10.20414/jurkom.v12i2.2739

Usman, M. H., Aswar, \& Irawan, A. W. (2020). Syariat islam dan kemashatan manusia di era new normal pada kegiatan keagamaan dan pendidikan. FENOMENA : Jurnal Penelitian, 12(1), 89-106. 
Yatimah, D., Kustandi, C., Maulidina, A., Irnawan, F., \& Andinnari, S. R. (2020). Peningkatan Kesadaran Masyarakat tentang Pencegahan COVID-19 berbasis Keluarga dengan Memanfaatkan Motion Grafis di Jakarta Timur. Jurnal Karya Abdi Masyarakat, 4(2), 246-255. https://doi.org/10.22437/jkam.v4i2.10530 